\title{
Report Receiver Receipt Date
}

National Cancer Institute

\section{Source}

National Cancer Institute. Report Receiver Receipt Date. NCI Thesaurus. Code C95390.

The date on which the report was received by the recipient. 